Goldschmidt 2021 Abstract

https://doi.org/10.7185/gold2021.5679

\section{Controls of climate and organic matter on uranium fluxes to lake sediments over the Holocene}

PIERRE LEFEBVRE ${ }^{1}$, PIERRE SABATIER ${ }^{2}$, ARNAUD

MANGERET $^{3}$, ALKIVIADIS GOURGIOTIS ${ }^{3}$, PIERRE LE PAPE $^{1}$, ANNE-LISE DEVELLE $^{2}$, PASCALE LOUVAT ${ }^{4}$, OLIVIER DIEZ ${ }^{3}$, JEAN-LOUIS REYSS ${ }^{2}$, JÉRÔME

GAILLARDET $^{5}$, CHARLOTTE CAZALA $^{3}$ AND GUILLAUME MORIN ${ }^{1}$

${ }^{1}$ Institut de Minéralogie, de Physique des Matériaux et de Cosmochimie (IMPMC), UMR 7590 Sorbonne UniversitéCNRS-MNHN-IRD

${ }^{2}$ Université Grenoble Alpes-Université Savoie Mont BlancCNRS-EDYTEM, UMR 5204

${ }^{3}$ Institut de Radioprotection et de Sûreté Nucléaire (IRSN), PSEENV SEDRE

${ }^{4}$ Université de Paris-Institut de physique du globe de ParisCNRS, UMR 7154

${ }^{5}$ Université de Paris-Institut de Physique du Globe de ParisCNRS, UMR 7154

Presenting Author: pierre.lefebvre@sorbonne-universite.fr

One of the main factors controlling the behavior of uranium (U) in water bodies is bottom water oxygenation, which enables the use of $U$ isotopic ratios and concentration in oceanic sedimentary records as paleo-redox proxies [1]. Here, we investigated the mechanisms governing $U$ accumulation in the sediments of Lake Nègre (2354 $\mathrm{m}$ above sea level, Mercantour Massif, France) over the past 9200 years. These sediments display exceptional natural $\mathrm{U}$ concentrations $\left(300-1500 \mu \mathrm{g} \cdot \mathrm{g}^{-1}\right)$, allowing for the first time the use of high-resolution X-Ray Fluorescence core-scanning for the measurement of $U$. Geochemical proxies ( $\mathrm{Ti}$ content and $\mathrm{K} / \mathrm{Ti}$ ratios) indicate that erosional sedimentary inputs were controlled by Holocene climatic variations. After a period of low erosion during the Holocene Climatic Optimum, a major regime shift was recorded at $4.2 \mathrm{kyr}$ BP when terrigenous fluxes increased until present with high sensitivity to centennial-scale climatic variations. The temporal evolution of carbon to nitrogen $(\mathrm{C} / \mathrm{N})$ and bromine to organic carbon $(\mathrm{Br} / \mathrm{TOC})$ ratios indicate that sedimentary organic matter (OM) was mostly of terrigenous origin from the catchment soils until $2.4 \mathrm{kyr}$ BP. From $2.4 \mathrm{kyr}$ BP to present, lake primary production and soils equally contributed to sedimentary OM. The Fe/Mn core profile points out that the lake bottom water oxygenation remained constant over the past 9200 years. Uranium depositional conditions were also constant over this period as attested by the ${ }^{238} \mathrm{U} /{ }^{235} \mathrm{U}$ (expressed as $\delta^{238} \mathrm{U}$ ) and $\left({ }^{234} \mathrm{U} /{ }^{238} \mathrm{U}\right)$ ratios. However, $\mathrm{U}$ fluxes to the sediments varied substantially and were correlated to terrigenous OM fluxes from 7 kyr BP to present. This correlation highlights that U supply to the lake was controlled by U scavenging in soils of the watershed followed by transport of $U$ bound to detrital organic particles. The fluctuations of $U$ sedimentary inputs thus appear to be controlled by climate-driven variations in terrigenous OM production and erosion, rather than by changes in bottom water oxygenation. This finding confirms that the use of $U$ (and potentially other metals with high affinity to $\mathrm{OM}$ ) concentrations alone should be used with caution for paleo-redox reconstructions.

[1] Lau et al. (2019) The uranium isotope paleoredox proxy. Cambridge University Press. 